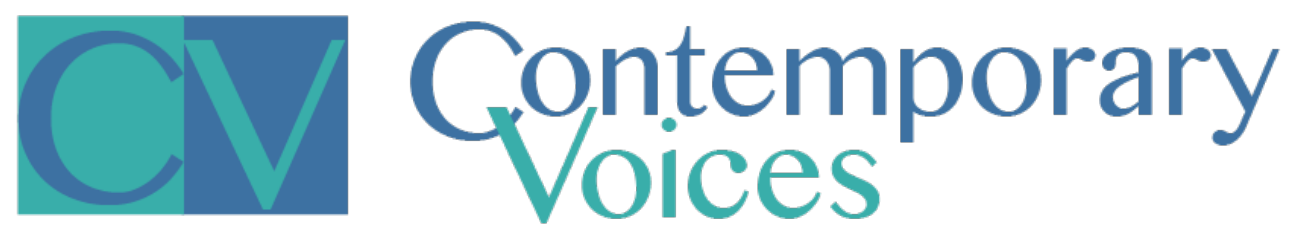

\title{
Book review: Mobilising the diaspora
}

\author{
by Daria Vorobyeva
}

The attention of both academics and policymakers working in such broad areas of enquiry as international relations, anthropology, political theory and transnational politics to name a few, has long ago turned towards the relationship between diaspora and homeland. More recently, the importance of the diaspora's influence on the political life of the homeland has started to come more to the fore of scholarship. It has been acknowledged that a politically mobilised diaspora can challenge the homeland state by using political or material leverage (diaspora members often have developed links to their host states and so can influence the latter's policies towards the homeland). Yet, only limited scholarship has emerged in international relations, comparative politics or diaspora studies on the mechanisms and patterns of diasporic transnational political mobilisation (see Chapter 1 of the book).

Mobilising the diaspora by Alexander Betts and Will Jones is a fascinating and significant book for scholars and political analysts, who desire to understand why certain diasporas are politically mobilised, whether (and how) their activities influence politics at home, why they choose specific tactics to reach their goals, and which factors define the birth and death of a diaspora. The examination of these questions is the prime goal of the authors. The development of a theory of a diaspora's 'life cycle' and the classification of factors defining its strategies can be seen as the main theoretical contributions of the book. The authors define a diaspora's 'life cycle' as 'its birth, life, death, and afterlife' (Betts and Jones, 2016, p. 215), which is seen as a dependent variable, while 'animators' - the actors causing mobilisation and providing various resources for a diaspora - are seen as an independent variable. The work also adds to the scholarship on transnational political mobilisation and contemporary African history - particularly in the context of Zimbabwe and Rwanda - as well as to the scholarship examining the role of the church in assisting refugees, and political mobilisation in the Global South. Generally, the book pleasantly surprises the reader with the rationality and openness of the debates provided.

One of the most thought-provoking statements of the book is that the mobilisation of a diaspora, which is seen as a politically active group, is 'an inherently political process - it has an underlying political economy [...] [and it] is based upon an underlying set of interests and power relations' (Betts and Jones, 2016, p. 7). The nature of this process and the 'animators', who are seen as allocators of financial, ideological and networking resources, define the life of diasporic mobilisation (see Chapter 1). Animators can be host country governments and other relevant host country actors, government or certain political actors in home countries, third country institutions (such as the British Foreign and Commonwealth Office in the case of the Zimbabwean diaspora), international organisations or civil society members. Probably the most interesting inquiry of the work in this regard is the analysis of the role of external actors in a diaspora's political mobilisation. The authors state that where animators are primarily external (host governments, third countries, IOs, external political parties or actors etc.), the sustainability of diasporic political activity is weaker. The reason for this is that such activities are closely linked to external resources, and once external animators reach their goals or change their priorities, the funding decreases or disappears, leaving the diaspora drifting. In such circumstances, diaspora members can either try to continue humanitarian work 


\section{Gontemporary \\ Volces}

with the limited resources available or try to attract external funding by emphasising goals that are attractive to external animators. Additionally, external animators are interested in their goals rather than the goals of a diaspora, while cooperating only as long as these aims coincide. Meanwhile, in cases of primarily internal animation, the life cycle of a diaspora is likely to be more sustainable, as internal actors are less likely to disappear suddenly. Finally, the authors prove through their case studies that institutionalised diasporas are more likely to sustain their activities in the longer term than network-based ones, as activities of the former are more structured and less dependent on individuals who may lose interest or change their agenda. This is an important breakthrough for diaspora studies, as principally this theory allows one to foresee diaspora activities and their chances of success regarding homeland political influence in the short, mid and, to some extent, the long term.

The two case studies selected, the Zimbabwean diaspora - mostly concentrating on South Africa since 2003 (Chapters 2-4) - and the Rwandan - primarily in the UK and the USA (Chapters 5-7) - allow the authors to test their theory in practice. Applying the theory of diaspora mobilisation, Betts and Jones track and explain the specifics of the birth, growth, death and after-life cycles of diasporas. On the one hand, both cases represent diasporas from authoritarian states. On the other, key animators differed in the two studies: in the case of the Zimbabwean diaspora political activities were primarily supported by outside players, while in the case of Rwanda, the homeland government has played a key role in its activities. In both cases, the theory proved to explain correctly the political developments of the diasporas. In the case of Zimbabwe, once political changes took place and external animators shifted their priorities, largely network-based diaspora organisations started drifting, while the Rwandan diaspora has been largely animated by the Rwandan government and institutionalised, which, as the authors show, allowed it to become more durable.

The book has several minor shortcomings. Although it sounds very intriguing, the title does not precisely describe its content, which may reduce its potential audience. First, the book largely focuses on the role of 'animators', including their actions in relation to political economy, and how the type/nature of animators influences the life cycle of a diaspora. The first case study shows how external animators support diaspora claims as long as these coincide with their own goals, while the second shows how an authoritarian state, to a large extent, shapes diaspora political mobilisation. The book, therefore, extensively discusses how external players mobilise diasporas against or in support of an authoritarian home state, and not primarily how diasporic groups themselves challenge these states. Consequently, a more fitting title for the book might be 'Diaspora political mobilisation: who and what defines the process?'.

It would further benefit the quality of the book if the part of the conclusion discussing the main arguments in modern diaspora scholarship (Betts and Jones, 2016, p. 214) was slightly expanded. At present, it does not exactly reflect the discussion in the introduction (Betts and Jones, 2016, pp. 2025), where authors provide a well-structured and rather strong literature review. It is acknowledged in the introduction that, recently, diasporas have been primarily seen in constructivist standings, i.e. as socially constructed, developing and 'imagined' (in Anderson's terms) entities, rather than fixed units. These arguments have been extensively discussed by such authors as Cohen (1997), Tölölyan (2007), Berns-McGown (2006; 2007) and Payaslian (2007). In the conclusion, however, it is claimed that 'the literature on diaspora politics tends to take the diaspora as given' (p. 214). This is a debatable statement and may, therefore, be confusing for readers who have only just begun working in the field of migration and diaspora studies, especially if they form their outlook by reading only the conclusion. These are, however, minor remarks, which should not distract the reader from the strong arguments provided. 
The book contributes to several disciplines and fields of study, such as diaspora and migration studies, political science, international relations and the contemporary political history of Rwanda, Zimbabwe and central Africa in general. The book will be beneficial to scholars in the abovementioned fields, as well as to political analysts and policymakers in state and non-state institutions. The theory on internal and external animation and its effect on the life cycle of a diaspora has the potential to be used to explain the life cycles of other political or even military groups. It would be interesting to examine, for example, the life cycles of prominent political and military opposition groups during revolutions and coups in authoritarian states. The best example that springs to mind here regards the Syrian war, and the life cycle of such primarily externally animated organisations as the Free Syrian Army, which had a prominent beginning but once the priorities of external animators changed, the political effectiveness of the organisations started to fail.

\section{Bibliography}

Berns-McGown, R. (2007) 'Redefining "diaspora": the challenge of connection and inclusion', International Journal, 63 (1), pp. 3-20.

Betts, A. and Jones, W. (2016) Mobilising the diaspora: how refugees challenge authoritarianism. Cambridge: Cambridge University Press.

Cohen, R. (1997) Global diasporas: an introduction. 2nd edn. London: Routledge.

Payaslian, S. (2007) 'Diasporan subalternities: the Armenian community in Syria', Diaspora: A Journal of Transnational Studies, 16 (1/2), pp. 92-132.

Tölölyan, K. (2007) 'The contemporary discourse of diaspora studies', Comparative Studies of South Asia, Africa and the Middle East, 27 (3), pp. 647-655. 